\title{
Iglesia de San Esteban Protomártir de Torrejón de Velasco (Madrid). Orígenes y primeras restauraciones
}

\author{
Church of St. Stephen Protomartyr of Torrejón de \\ Velasco. Origins and early restorations
}

\author{
MARÍA JosÉ Velasco EsteBAN \\ Doctora en Comunicación Audiovisual. Universidad Complutense de Madrid (España) \\ majozeve@hotmail.com
}

Recibido: $12 / 01 / 2014$

Aceptado: $17 / 03 / 2014$

\begin{abstract}
Resumen
Torrejón de Velasco es una localidad situada a $33 \mathrm{~km}$. de Madrid, en la A-42, carretera que une la capital con Toledo. En los últimos años, durante el curato de D. Alberto Velasco, la iglesia parroquial de San Esteban Protomártir, monumento catalogado como BIC (Bien de Interés Cultural) pasó por un profundo y largo proceso de obras, realizadas a partir de un plan general de restauración que abarcó desde los cimientos hasta la cubierta. Para realizar dicha restauración, Patrimonio Nacional así como el arquitecto encargado de dicho plan, Jose Luis Alonso García, solicitaron a la parroquia cualquier tipo de documentación que mostrase cómo era el templo antes de la Guerra Civil Española, ya que había perdido la torre en un bombardeo durante los
\end{abstract}


primeros días de la contienda y salvo un par de fotografías, no existía ninguna otra documentación. El plan de restauración contemplaba la reconstrucción del desaparecido chapitel, algo que sería un auténtico hito para los vecinos del pueblo, principalmente para los más mayores, que sin duda conservaban en sus retinas la lejana estampa de la torre de la iglesia, recortando el horizonte, alzándose, majestuosa, con su chapitel imponente, sobre de los páramos de la comarca de la Sagra. Para tal fin, y por iniciativa del párroco, recibí el encargo de documentar el edificio a partir de los pocos documentos conservados en el archivo parroquial, saqueado al inicio de la guerra junto a la mayor parte los objetos artísticos y de la liturgia del templo, y la información, más abundante, conservada en archivos particulares y en los fondos de los Archivos Diocesano e Histórico Nacional, que permitieron sacar a la luz documentación inédita que ahora presentamos como parte de la investigación realizada, centrándonos en el estudio de los orígenes del templo y sus principales reformas y restauraciones históricas.

\title{
Palabras clave
}

Iglesia de San Esteban Protomártir, Torrejón de Velasco, restauración, patrimonio, Bartolomé Zumbigo y Salcedo.

\begin{abstract}
Torrejón de Velasco is a village located from $33 \mathrm{~km}$ from Madrid, in the A-42 road linking the capital to Toledo. In recent years, in the parish of D. Alberto Velasco, the parish church of St. Stephen Protomartyr, monument listed as BIC (Building of Cultural Interest) went through a deep and lengthy plan of restoration, from the the foundations to the roof. National Heritage and the architect charged of the restoration plan, Jose Luis Alonso Garcia, to achieve this restoration asked the parish for any documentation that showed how was the temple before the Civil War, as it had lost the tower in a bombing during the early days of the war, and only couple of pictures were the unique documentation. The restoration plan provided for the reconstruction of the missing spire, which would be a milestone for the inhabitants, especially for the olders, who keep in their eyes the distant picture of the church tower, raising the horizon majestically over the moors of the region of the Sagra, with its imposing spire. I was asked to document the building from the few documents that were kept in the parish archives, sacked at the beginning of the war with most of art objects and liturgy of the temple, and with information conserved in private archives, National Historical Archive and Diocesan Archives, which allowed to expose unpublished documents which we present now as part of the research, focusing in the study of the origins of the temple tions and major renovations and historic restorations.
\end{abstract}




\section{Keywords}

Church of St. Stephen Protomartyr, Torrejon de Velasco, restoration, heritage, Bartolomé Zumbigo Salcedo.

Referencia normalizada: VELASCO ESTEBAN, MARÍA JOSÉ (2014): “Iglesia parroquial de San Esteban Protomártir de Torrejón de Velasco. Orígenes y primeras restauraciones". Arte y Ciudad. Revista de Investigación, no 5 (abril), págs. 67-98). Madrid. Grupo de Investigación Arte, Arquitectura y Comunicación en la Ciudad Contemporánea, Universidad Complutense de Madrid.

Sumario: 1.- Introducción.- 2.- Construcción de la primitiva iglesia y primeras reparaciones (1400-1603).- 3.- Las obras de ampliación (1603-1665). 4.- La caída de la torre (1665).- 5.- El proyecto de restauración de Bartolomé Zumbigo y Salcedo (1671).- 5.1.El proceso constructivo.- 5.2.- La continuidad del proyecto. Intervenciones a finales del siglo XVIII.- 6.- Nuevas obras y reformas en los siglos XIX y XX.- 7.- Fuentes Documentales.- 8.- Bibliografía.

\section{Introducción.}

Los primeros asentamientos humanos documentados de los que se tiene noticia en Torrejónde Velasco datan del siglo V d.C. Se trata de hallazgos tardorromanos o hispano-visigodos encontrados durante la construcción del gasoducto Madrid-Sevilla en 1990, conformados por un basurero ${ }^{1} \mathrm{y}$, a una distancia de unos 200 metros, restos de muros pertenecientes a una vivienda o villa, situados en una terraza que forma el arroyo Guatén (Geanini, 1991: 332334). Se encuentran ubicados a mitad de camino entre Torrejón de Velasco y Valdemoro, en las coordenadas $40^{\circ} 11^{\prime} 48^{\prime \prime}$ de latitud y $3^{\circ} 43^{\prime} 45^{\prime \prime}$ de longitud. En la actualidad estos restos arqueológicos han quedado cubiertos en su totalidad por la autopista R-4 pero gracias al estudio del arqueólogo Antonio

\footnotetext{
${ }^{1}$ En el basurero se encontraron gran número de tejas de elaboración manual y cerámica de cocina elaborada a torno así como clavos de metal, pequeños trozos de vidrio y restos óseos de animales de granja: cánidos, équidos y vacunos. Según el estudio de Geanini, los trozos de cerámica encontrados se corresponden con el periodo hispano-visigodo.
} 
Geanini y a las fotografías realizada de esos restos arqueológicos por un vecino de Torrejón de Velasco tenemos constancia de su existencia. Según Antonio Geanini no se trataba de un asentamiento humano de gran magnitud como para conformar un núcleo de población, sino más bien de una villa de explotación agraria, una construcción aislada de las que se solían dar en la periferia de poblaciones más grandes, algo similar a lo que hoy conocemos por cortijo o caserío. Estos hallazgos se corresponderían con la teoría de Andrés Martín Pérez en su Guía de Madrid y su Provincia (1888) según la cual en Torrejón de Velasco se asentó una familia hispano-romana y fueron ellos los que le dieron a la localidad el nombre de Torrejón, algo que algunos autores ponen en tela de juicio:

Una familia hispano-romana de las que quedaron en el centro de España bajo la dominación visigoda al destruirse para siempre el imperio romano fundo las primeras casas de este pueblo que denominaron simplemente Torrejón. Con éste nombre se conoció en todo el periodo visigodo y casi los dos primeros tercios de la Reconquista hasta que en el año 1332 fue cedido por don Sancho a don Sebastián Domingo, caluroso defensor y acérrimo partidario del indicado monarca (Martín Pérez, 1888: 409).

Pilar Martín-Serrano también hace referencia a pequeños hallazgos de la época imperial romana y Edad Media en el Cerro del Pleito, consistentes en restos de terra sigillata y cerámica medieval, así como restos de una villa romana del periodo imperial en el camino de Esquivias (Martín Serrano, 1991: 180). Todos estos vestigios de la época tardoromana y visigoda no son indicativos de que existiese un núcleo de población lo suficientemente grande como para construir en él un templo, aunque se sabe que Torrejón de Velasco se encuentra situado cerca de una vía romana secundaria que procedía del Norte de Madrid y que iba a Aranjuez, Esquivias y Toledo, pasando por Parla, Torrejón de la Calzada y Torrejón de Velasco (Díaz Prieto, 2005: 32).

Otra teoría mejor documentada y más estudiada es la que sustenta el origen árabe de Torrejón de Velasco. Son muchos los historiadores que han descrito la historia de Madrid durante el periodo de dominación árabe. En el siglo VII la región central en la que actualmente está Madrid se encontraba prácticamente despoblada. Se cree que Matrice, Madrid, era por aquel entonces un pequeño enclave visigodo (Montero Vallejo, 1987: 31-39), aspecto bas- 
tante debatido por los historiadores. Aunque la región estaba muy despoblada se conservaban las vías pecuarias romanas, que fueron aprovechadas por los musulmanes para su incursión hasta el centro de la península Ibérica. Para los musulmanes, que estaban consolidando sus posiciones en la península, esta región se convirtió en un enclave estratégico para desde aquí atacar a las regiones cristianas del norte. Así surge el ribat llamado Mayrit en época del emir Mohammad I (852-886) (Montero Vallejo, 1987: 55) como un núcleo amurallado de carácter religioso y militar, que fue levantado donde hoy se encuentra ubicado el Palacio Real, con su torre, fortaleza y recinto amurallado. Mayrit se fundó con la finalidad de organizar la yihad, la guerra santa contra los reinos cristianos.

Pero ¿qué relación existe entre Mayrit y Torrejón de Velasco? El territorio madrileño fue protegido por los musulmanes desde tres enclaves fundamentales: Mayrit, Talamanca y Qal'-at'-Abd-Al-Salam (Alcalá de Henares), situados estratégicamente en los tres ríos más importantes de la región y que a la vez eran importantes vías de comunicación: Talamanca en el río Jarama, Mayrit en el Manzanares y Qal'-at'-Abd-Al-Salam en el Henares. Estos núcleos estaban acompañados de otros emplazamientos con atalayas o torres defensivas ubicadas en lugares estratégicos y cuya finalidad era alertar de las posibles incursiones cristianas. Estas torres estaban organizadas en cuatro hileras: la primera hilera de torres se situó a lo largo del río Jarama, en el Berrueco, el Vellón, el Molar y Alcobendas. La segunda hilera de torres controlaba los pasos desde la sierra hacia Mayrit y se ubicaron en Torrelodones y Hoyo de Manzanares entre otros. La tercera hilera se situó a lo largo del cauce del río Manzanares para defender el camino entre Mayrit y Toledo, con torres en Torrejón de la Calzada, Torrejón de Velasco, Cubas y Valdemoro. La cuarta hilera de torres se ubicó a lo largo del río Guadarrama en Alamín y Almenares entre otros (Montero Vallejo, 1987: 61).

La cristianización de Madrid se inició cuando pasó a manos del Rey de Castilla Alfonso VI entre los años 1084 y 1086 (Segura Graino, 2002: 34-35). Así, "Torrejón", tal como se le denominó desde entonces, topónimo derivado de la torre o atalaya construida en éste lugar por los árabes, surgió como un enclave musulmán de carácter militar para la defensa de Mayrit. Por lo tanto no sería extraño pensar que de ese enclave surgiese un pequeño núcleo de población y que construyesen también una mezquita cercana para su culto. Sin embargo de 
esto último no hay constancia documental, ni restos arqueológicos que lo testimonien. Si bien la erección de templos cristianos sobre mezquitas árabes fue una práctica muy extendida en España, en Torrejón de Velasco no han quedado vestigios que evidencien esa posibilidad.

Nosotros nos inclinamos a creer que el primer templo cristiano erigido en Torrejón de Velasco se construyó cuando el lugar contó con población cristiana y estable, y que esto se produjo a raíz de las repoblaciones realizadas en la región a partir de los siglos XII y XIII. Madrid se convirtió en un lugar privilegiado a partir de la concesión del Fuero en el año 1202 que le permitió organizar la población de su demarcación y obtener tributos de estas localidades.

Los nuevos pobladores se asentaron en multitud de pequeños núcleos desperdigados por todo el territorio de Madrid. En la segunda mitad del siglo XIII surgen los primeros concejos aldeanos de la zona sur como el de Getafe (1252), Cubas o Griñón (1283) (Vigil-Escalera, 1997: 40). A mediados del siglo XIV se procedió a reestructurar esos pequeños núcleos aldeanos dispersos por la geografía del concejo madrileño produciéndose un trasvase de habitantes desde los poblados más pequeños a otros más grandes. Así por ejemplo, las aldeas de Pozuela y Palomero se despoblaron a favor de "Torrejón de Sebastián Domingo", como así se llamaba por aquellas fechas. En este proceso de reestructuración de la población, Torrejón de Sebastián Domingo quedó enclavado en la Comunidad de Villa y Tierra de Madrid, dependiente del Sexmo de Villaverde, gobernado por alcaldes y regidores elegidos por los vecinos de la localidad, que debían ser confirmados por Madrid (Martín Serrano, 1991: 181).

Puede decirse que a partir de este momento, mediados de siglo XIV, Torrejón de Sebastián Domingo contó con un núcleo de población suficiente, con su estamento político y administrativo organizado, y que el Arzobispado de Toledo no se demoraría en establecer en éste lugar una iglesia que asentara la fe cristiana de los vecinos. No hay que olvidar que estamos en plena reconquista y lucha contra los musulmanes y que la Península Ibérica contaba con una nutrida población judía. Hay que presuponer, por tanto, que desde esta época Torrejón de Sebastián Domingo contó con su templo cristiano, ya fuera una pequeña iglesia o una ermita.

Torrejón de Sebastián Domingo dependió de la jurisdicción del concejo madrileño hasta que en el año 1294 el rey Sancho IV hizo donación de ella a 
don Gonzalo Ruiz, alcalde mayor de Toledo, Señor de Orgaz y fiel servidor del Rey, convirtiéndose en dominio señorial. Cuando una de sus hijas se casó con el hidalgo López de Velasco, Torrejón de Sebastián Domingo formó parte de la dote matrimonial de la joven. Por un Privilegio Real, Lope de Velasco dio su apellido al topónimo con el que se conoció desde entonces a la aldea, a la que se le llamó Torrejón de Velasco, siendo confirmada esta donación por el rey Alfonso XI en 1343 (Bordejé, 1956: 199).

Se sabe que Torrejón de Velasco tuvo también población judía. Fidel Fita en su ensayo sobre La Judería de Madrid en 1391 habla de una carta del rey don Alfonso XI escrita el 29 de marzo de 1343 durante el asedio de Algeciras, en la que habla de los judíos de Parla, Torrejón de Sebastián Domingo y Polvoranca, aldeas de Madrid, los cuales se demoraban en el pago de sus tributos por las heredades que tenían en esas localidades (Fita, 1886: 463)².

Entre 1343 y 1400 Torrejón de Velasco pasó por distintas manos, aunque los datos históricos son muy imprecisos al ser todavía un periodo poco estudiado. Parece que Torrejón de Velasco fue heredado por el hijo de Lope, Sanz de Velasco. Se tiene constancia de una sentencia fechada en 1362 por el pleito entre Pero López de Ayala, casado con Leonor Núñez, vasallo del rey, y de la otra parte Sanz de Velasco, hijo de Lope de Velasco e Inés García su mujer, en la cual López de Ayala presentó ante el juez una carta del rey don Pedro I, sellada con su sello, dada en Almanzán el 26 de febrero 1361, en la que ordena a Velasco y a su mujer que devuelvan los maravedíes que recibieron de López de Ayala por la compra que hizo de las dos partes de Torrejón de los Velascos, término de Madrid ${ }^{3}$.

A principios de siglo XV Torrejón de Velasco era señorío de doña Leonor Fernández de Ayala, casada con Fernando Álvarez de Toledo, señor de Valdecorneja (Díaz Prieto, 2005: 34), la cual falleció en torno a 1420 (VigilEscalera, 1997: 42). Los inventarios curales citan como fecha de construcción

\footnotetext{
${ }^{2}$ Biblioteca Nacional: Aljamas, padrones, arrendamientos y otros papeles pertenecientes a los moros y judíos de Castilla. Carta de Alfonso XI, sobre la moratoria dada a los cristianos por las deudas de los judíos, 1341 (h. 56-57v). Idem, para que los judíos paguen tributos por las heredades que tuviesen en Toledo, Gálvez, Torre Esteban Ambran, Parla, Torrejón de S. Sebastián y Polvoranca, 1343. h. 58-59r.

${ }^{3}$ Archivo Histórico Nacional (AHN) Sección Clero Caja. 3.072
} 
de la iglesia de San Esteban Protomártir el año 1400. Como vemos, en ese momento Torrejón de Velasco era señorío de doña Leonor Fernández de Ayala, y reinaba en Castilla Enrique III llamado El Doliente (1390-1406). En los años en que supuestamente fue erigida esta iglesia eran Obispos de Toledo don Pedro Tenorio, Arzobispo de Toledo de 1377 a 1399, famoso por su actividad en obras eclesiásticas y civiles, así como don Pedro de Luna, sobrino del célebre antipapa, el cual lo nombró Arzobispo de la Sede Primada en 1405, con gran disgusto de Enrique III porque era extranjero (De Andrés, 1986: 11). Le sucedió en el cargo don Sancho Rojas de 1415 a 1422.

\section{Construcción de la primitiva iglesia y primeras reparaciones (1400-1603).}

Por los datos aportados en alguno de los inventarios de los curas propios de esta iglesia, el edificio fue levantado, sin poder precisar con exactitud, en el año 1400. Los curas recogen esta información para dejarla por escrito pero aseverando que desconocen si es cierto o no. Realmente la fecha de 1400 para la construcción de la iglesia no es un dato descabellado. Se sabe que en 1424 la iglesia de Torrejón de Velasco ya era inspeccionada por el arcediano enviado por el Obispo de Toledo, teniendo en esa fecha sus tierras, edificio y ornatos, con lo cual su construcción se realizaría años antes.

Este templo fue edificado todo de sillería, bastante alto, con una sola nave, ábside de cinco lados, crucero y sobre éste una cúpula vaída sobre pechinas, bóveda de cañón, y cubierta a cuatro aguas en teja árabe, todo ello sustentado por sólidos contrafuertes. La iglesia contaba con una pequeña sacristía adosada al brazo del crucero, en la parte de Levante. Tenía su puerta de acceso al templo en el lado de Mediodía y otra puerta pequeña por la que se podía acceder al terreno que poseía la iglesia en el lado de Poniente.

Esta iglesia no se levantó sobre ninguna otra anterior que se sepa. Era de tipo parroquial, es decir, destinada a la cura de almas, regida por un presbítero o cura propio y dependía directamente del Arzobispado de Toledo. Las iglesias de nueva construcción no se edificaban sin una causa justificada y $\sin$ licencia del Obispo. Cuando llegaba el caso se procuraba que esa iglesia se pudiese sostener económicamente, por lo que era necesario dotarla de un beneficio, es decir, de bienes que produjesen rentas para el sostenimiento del culto y de los ministros. La iglesia de San Esteban tenía sus bienes y rentas. 
En 1427 el Obispo de Toledo don Juan Martínez Contreras ordena una inspección de todas las iglesias del arcedianato de Madrid, incluidas las del alfoz, tras haber sufrido la región una pertinaz sequía que acabó con muchas cosechas (interesaba sobre todo el estado económico de las iglesias, de ahí que los informes del visitador fuesen puramente económicos, dando sólo pequeñas anotaciones sobre los ornamentos). El trabajo fue encargado a un clérigo de nombre Martín Sánchez de Madrid, ayudado por dos notarios públicos, Alfonso Martínez, que ejerció su oficio de notario en las iglesias de fuera de la villa y Luis González de Riaza para las de la villa (De Andrés, 1986: 14). El 23 de enero de 1427 la iglesia de San Esteban recibió la visita eclesiástica que tomó nota de sus bienes:

Frutos: 13 fanegas de trigo con 2 celemines y 26 fanegas de cebada con 8 celemines. Rentas: 285 maravedies, 2 dineros y 4 meajas. Los objetos sagrados son los corrientes. La Iglesia tiene trece aranzadas de viñas y 6 fanegas de tierras, más dos cubas y nueve tinajas entre sanas y quebradas. Hay un beneficio curado y otro prestamero, que tiene el deán de Toledo (De Andrés, 1986: 31-32).

Los beneficios o rentas no sólo mantenían económicamente a la iglesia en cuestión, sino también al Arzobispado. De ahí que en muchas ocasiones se diese el caso de iglesias que estaban en despoblados, atendidas por clérigos unos días a la semana y que se mantenían en activo por las rentas que producían, no por los feligreses que acudiesen a ellas (que en ocasiones no tenían). Eso ocurría por ejemplo con la iglesia de Palomero, visitada el 22 de enero de ese año, ya despoblado en esa fecha tal como indicaba el visitador:

Frutos: 194 fanegas de trigo con 8 celemines y medio; 152 fanegas de cebada con 6 celemines y medio. Rentas: 33 maravedíes con 5 dineros. Hay un beneficio curado más una prestamería, que tiene el arcediano de Talavera. Los objetos sagrados son los corrientes. Los altares están mal aparejados. Posesiones de la iglesia: quince aranzadas de viñas buenas, cuatro fanegas de viñas mal labradas y diez fanegas de tierra. El visitador indica al mayordomo que en la iglesia "había asaz cosas de reparar y de hacer en ella, que pusiese por obra a lo facer reparar, lo cual le requirió antes testigos (De Andrés, 1986: 30-31).

La iglesia de Palomero se mantuvo en pie durante siglos. Don Josef Mingo López, Párroco de San Esteban Protomártir, daba cuenta de ella en 1786 en las Descripciones del Cardenal Lorenzana: 
Y a parte de Mediodía a distancia de media legua, está la iglesia que fue del despoblado de Palomero, en donde se venera la efigie milagrosa de Jesucristo crucificado advocada del Buen Camino (Martín Galán, 1992: 380)4.

De las rentas obtenidas del beneficio curado, la parroquia debía entregar los diezmos eclesiásticos. En 1484, a través de un monitorio apostólico o amonestación emitida por Juan González de Ocaña, sabemos que la iglesia de San Esteban Protomártir tenía dos arrendadores del pan pontifical, los hermanos Yusuf Cidre y Abrahen Cidre, junto con su cura propio, don Fernando González, los cuales fueron denunciados por Pedro Ximenez, clérigo, ya que debían 194 fanegas de trigo ${ }^{5}$. El pan pontifical era una parte de los diezmos eclesiásticos, el tercio de fábrica de los diezmos correspondientes a la iglesia y que procedía básicamente de la venta de trigo y cebada, también llamado tercia pontifical (Martín Martín, 2003: 58). Como vemos, el cobro de los diezmos podía ocupar a varias personas.

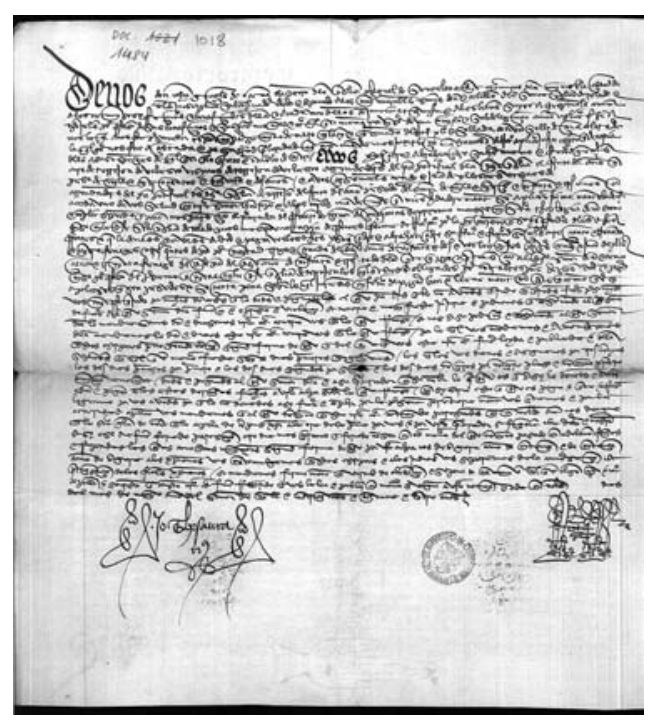

Fig 1. Archivo Histórico del Monasterio de Santo Domingo el Real. (Toledo) Documento $\mathrm{n}$ - 1018. Año 1484. Monitorio apostólico por el cual Juan González de Ocaña, saluda a Yusuf Cidre y Abrahen Cidre, su hermano y Fernando González, cura de Torrejón de Velasco, arrendadores del pan pontifical de este lugar, para que paguen 194 fanegas de trigo que deben.

\footnotetext{
${ }^{4}$ La iglesia de Palomero, seguramente por quedar en ruina, fue vaciada y sus bienes repartidos entre otras iglesias en el siglo XIX. Algunos de los vecinos más mayores de Torrejón de Velasco, recuerdan haber visto en la parroquia un Cristo al que llamaban "Cristo de Palomero" afirmando que fue traído de esa iglesia. Este Cristo también figura en el inventario del Párroco don Narciso Martín escrito a finales del siglo XIX y como el resto de las imágenes que había en la parroquia de San Esteban Protomártir, fue destruido durante la guerra de 1936.

${ }^{5}$ Archivo Histórico del Monasterio de Santo Domingo el Real (Toledo), № 1018.
} 
El Párroco de la iglesia de San Esteban, don Ambrosio Mimbreño de la Barrera tuvo bajo su responsabilidad todos los reparos de la iglesia de los que hay constancia desde 1585, buena parte de la ampliación que se hizo desde 1603, y fue testigo y asesor en la conformación de las hermandades más antiguas de la parroquia (Virgen del Rosario, Sacramental, San José...) estando presente y firmando como testigo en la creación del convento de religiosos Trinitarios Descalzos en 1606.

\section{Las obras de ampliación (1603-1665).}

Desde 1582 la iglesia venía sufriendo grandes desperfectos en su cubierta que producían goteras y que la dejaron casi en ruina. El cura propio, don Ambrosio Mimbreño empezó a solicitar al Arzobispado de Toledo el embargo de las rentas decimales para invertirlas en las reparaciones. Así fueron pasando los años, sosteniendo una iglesia estructuralmente muy deteriorada y parcheando los desperfectos del templo cuando había dinero, pero sin lograr sacarlo de su estado ruinoso. Además había otro problema: la población de la Villa de Torrejón de Velasco había crecido mucho desde el año 1400 y durante las misas y especialmente los días de fiesta religiosa, la mitad de la gente se quedaba fuera del templo porque no cabían.

En el año 1603 la situación era insostenible, así que don Ambrosio escribió una carta al Arzobispado de Toledo para solicitar el embargo de las rentas decimales, no ya para hacer reparos sino para hacer una obra profunda en la iglesia que incluyese su ampliación. Por esta carta sabemos que la cubierta en la parte de la tribuna, a los pies de la iglesia, estaba en tan mal estado y tan desbaratada que se llenó la bóveda de goteras y cuando llovía se inundaba todo de agua, hasta el Altar Mayor. La cubierta y bóveda de la iglesia estaban apuntaladas y lo que es peor, una gran viga de madera que sustentaba todo el cuerpo de la iglesia se estaba quebrando, lo cual, según el Párroco, era muy peligroso para los feligreses y sacerdotes. Se lamentaba también de que sólo iban tres o cuatro fieles a la Misa Mayor ya que el resto tenían miedo a que se les hundiese la iglesia encima.

No había retablo en el presbiterio, ni torre, ni campanario y el cura llamaba al pueblo con una campanita sujetada por unos maderos que apoyaban en la pared, pero estaba colocada tan baja que cualquiera que pasase la podía hacer 
tañer y no se podía poner más alta por el peligro a que se desprendiese. La iglesia no tenía ornamentos y los que tenía estaban en tan mal estado que no los sacaban. Solo tenían una cruz vieja, una custodia, un incensario y tres cálices, todo de muy poco valor y conseguido a base de limosnas. En cuanto a la fábrica de la iglesia (en referencia los bienes en tierras) tenía la iglesia ciento veinte fanegas de trigo, pero no todos los años había cosecha.

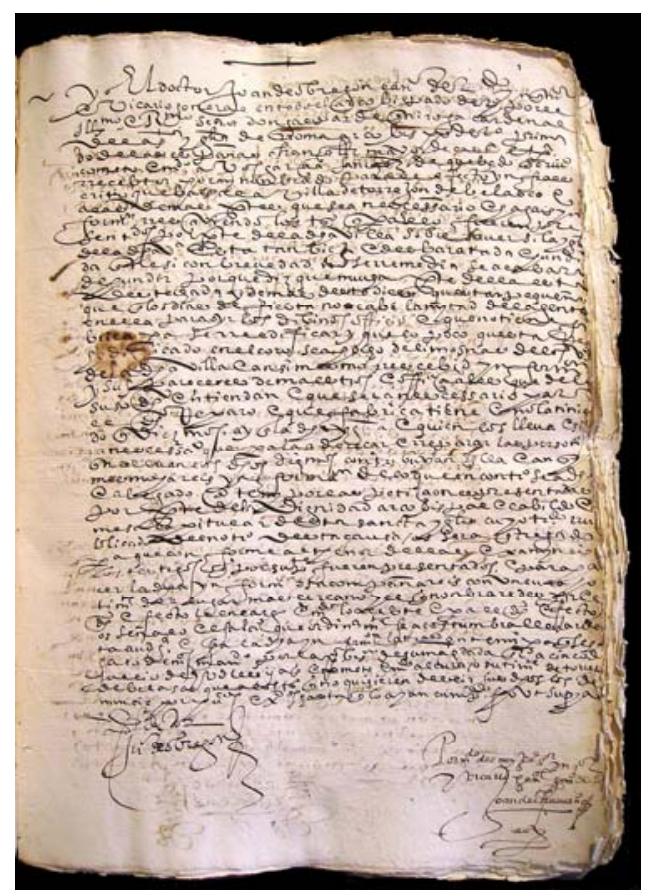

Fig. 2. Archivo Diocesano de Toledo. Reparación de Templos. Torrejón de Velasco. Legajo. Ma. 9 Expediente 21. Año 1582. Solicitud del embargo de las rentas decimales para reparos y fábrica de la iglesia.

El Párroco entendía que había que hacer todo el cuerpo de la iglesia de nuevo y agrandarla, ya que antes de caer en esa ruina no cabía ni la mitad de la gente y que por otro lado, lo poco que había edificado se había hecho todo de limosnas y para la obra que quería hacer hacía falta una gran suma de dinero ${ }^{6}$. Por todo ello don Ambrosio Mimbreño de la Barrera solicitó al Arzobispado de Toledo y posteriormente al Concejo de Justicia y Regimiento de la Villa de Torrejón de Velasco licencia para que fuesen embargadas las tercias de las rentas decimales y destinarlas a la fábrica de la iglesia. El Alcalde Mayor del

${ }^{6}$ Archivo Diocesano de Toledo. Reparación de Templos. Torrejón de Velasco. Legajo: Ma. 9 Exp. 21 
pueblo recibió la Real Provisión con la licencia para embargar esas rentas el 26 de enero de 1603, haciendo llegar las pertinentes formalidades al Consejo de la Gobernación del Arzobispado de Toledo. El Arzobispado le dio a don Ambrosio Mimbreño un plazo de ocho años para hacer las obras.

El Párroco solicitó al Arzobispado que enviasen a su Maestro Mayor de Obras para que viese la iglesia e hiciese la traza, presupuesto y condiciones de la construcción. La obra costaría 24.000 ducados, lo cual resultaba muy caro para las posibilidades del pueblo. Por ello se hizo según la traza del maestro de obras Francisco de las Eras por 15.000 ducados. Las obras no se iniciaron hasta que no hubo el suficiente dinero recaudado: era el 2 de mayo de $1608^{7}$.

Los trabajos de construcción del nuevo templo no se realizaron en los ocho años acordados. Muy al contrario, resultó una tarea lenta y llena de pleitos derivados de la reticencia del Arzobispado de Toledo a seguir dando licencia para embargar el tercio de los diezmos, lo cual paralizaba y retardaba las obras, para desesperación de su Párroco, que veía a los feligreses sin templo.

Desde el punto de vista arquitectónico y artístico, la ampliación de la iglesia obligó a adaptar la construcción primitiva, con influencias medievales, a las nuevas tendencias arquitectónicas de gustos barrocos que imperaban en el Madrid de la época, sin olvidar las influencias toledanas, procedentes de los maestros alarifes, maestros de obras y arquitectos que eran enviados desde el Arzobispado de Toledo. Así la ampliación de la iglesia dio como fruto un templo de planta de cruz latina realizado en ladrillo de tejar de color pardo rojizo $^{8}$ con cajones de mampostería y contrafuertes de ladrillo, con su Capilla Mayor mucho más larga, cubierta por la misma bóveda de cañón que tenía la iglesia primitiva, sustentada por arcos fajones. En el lado de poniente de la Capilla Mayor se construyeron dos capillas laterales, aprovechando los espacios entre contrafuertes (las actuales capillas del Cristo de la Ascensión y San José) y entre ellas se abrió una puerta de entrada y salida al templo.

En el otro lado de la Capilla Mayor, se hizo otra puerta de acceso justo enfrente de la anteriormente mencionada. A la izquierda de ésta se construyó

\footnotetext{
${ }^{7}$ Archivo Diocesano de Toledo. Idem. Legajo: Ma. 9 Exp. 22.

${ }^{8}$ José Luis Alonso García. Plan Director para la Restauración de la Iglesia Parroquial de San Esteban Protomártir en Torrejón de Velasco (Madrid). Pág. 27. Archivo Parroquial de San Esteban Protomártir. Torrejón de Velasco (Madrid).
} 
una capilla con una profundidad igual a la del brazo del crucero (la Capilla de Nuestra Señora de la Salud, primera advocación de la Capilla de los Hierros) y a la derecha de la puerta, se hizo una capilla bajo arcosolio. La tercera puerta de entrada y salida al templo se abrió como en la iglesia primitiva, en el lado de Mediodía, a los pies de la iglesia, con su pórtico. Sobre ella se levantó una tribuna o coro, sustentada por una sólida columna a modo de viga.

La iluminación del templo con luz natural procedía de los lunetos ojivales superiores, que aportaban a la iglesia una luz muy difusa. Para finalizar, se levantó la torre campanario adosada al templo junto a la puerta del lado de Mediodía, compuesta de tres cuerpos de ladrillo árabe y cajones de mampostería, con su chapitel de pizarra, veleta, bola y cruz. La torre tenía casi el doble de altura que la iglesia, por lo que aumentó la sensación de esbeltez del edificio. Toda la construcción, tanto interior como exterior, se caracteriza por su austeridad decorativa, prácticamente inexistente.

La Capilla Mayor fue terminada aproximadamente en el primer cuarto del siglo XVII. En las constituciones de la Hermandad de San José de $1621^{9}$ se menciona que los hermanos se reunieron en la ermita de San Nicasio para escribir sus primeros estatutos, quizá porque las obras de la iglesia les impedían reunirse en ella. Sin embargo desde 1626 sí hicieron reuniones dentro de la iglesia. Además hay constancia de que se estaban realizando enterramientos dentro del templo en torno a $1623^{10}$, lo cual indica que para esas fechas estaba concluida. Poco después pero siempre antes de 1650-5111, se terminó de construir la Capilla de Nuestra Señora de la Salud. En 1648 se instaló en la tribuna un órgano realizado por Nicolás de Mayo, comprado en Toledo, de marrón flamenco, con un precio de 11.900 maravedíes. Su traslado desde Toledo e instalación en la iglesia costó 4.764 maravedíes ${ }^{12}$. Este órgano fue revisado por el Maestro de Órganos Gabriel Salazar en $1655^{13}$. La torre se terminó de cons-

\footnotetext{
${ }_{9}^{9}$ Archivo Parroquial de San Esteban Protomártir. Torrejón de Velasco. C (1) EST. San José. 1621 ${ }^{10}$ Archivo Histórico de Protocolos Notariales de Madrid. P. 3597, Fol. 1957v-1959v. Petición de Francisco Martín Tamborino, de profesión entallador, para ser enterrado dentro de la iglesia de Torrejón de Velasco, 26 de noviembre de 1623.

${ }^{11}$ Se sabe que esta capilla estaba concluida en 1650 ya que en 1651 don Antonio Sevillano Ordóñez quiso hacer en su interior su enterramiento para él y sus descendientes.

${ }^{12}$ Iglesia Parroquial de Torrejón de Velasco. Libro de Fábrica I. Fol. 273 (Martín, 1942: 4).

${ }^{13}$ Op. Cit. Fol. 275.
} 
truir en 1650 y la escalera de caracol interior, obra del maestro Cristóbal Rodríguez, se terminó en $1652^{14}$.

La iglesia estaba prácticamente concluida en 1654. Sólo faltaba terminar la ampliación de la sacristía y hacer un baptisterio a las espaldas de la Capilla de Nuestra Señora de la Salud. En ese año el Arzobispado de Toledo y el Párroco, junto con el Mayordomo de Obras de la parroquia, firmaron un "acuerdo de concordia" por el cual, el Arzobispado se comprometía a seguir destinando las tercias correspondientes a la parroquia para terminar las obras que quedaban pendientes, cuya cuantía sería una cantidad de dinero cerrada. A cambio la parroquia se comprometía a buscar por sus medios a los maestros de obras de su elección (los cuales aportarían las garantías y fianzas sobre las obras que realizasen) y a asegurar que todo lo construido se mantendría en pie por un tiempo no inferior a 50 años ${ }^{15}$.

La firma del acuerdo de concordia con el Arzobispado era indicativo de que todo se estaba desarrollando bien. Muestra de ello es que se había superando la fase de fábrica de la iglesia y ya se estaba invirtiendo en el ornato interior del templo. De hecho el Mayordomo de Fábrica, Francisco de Salas y Alfaro, había empezado ya a recibir dinero a cuenta del retablo del Altar Mayor.

En esas deliberaciones estaban cuando a principios de 1665 ocurrió lo peor, el mayor de los desastres: la torre, que estaba terminada desde hacía 15 años, se hunde, desplomándose sobre la iglesia, causando grandes destrozos y desbaratando todo el presupuesto de la iglesia.

\section{La caída de la Torre (1665).}

Por orden del Consejo de la Gobernación del Arzobispado de Toledo, se encargó a Diego de Benavides, Maestro de Albañilería de la ciudad de Toledo que fuese a Torrejón de Velasco para revisar el templo y hacer un presupuesto de obras para terminar de construir lo que faltaba y arreglar todos los destrozos ocasionados por la caída de la torre (sin especificarse con qué dinero se harían esas obras... importante tema como veremos después). El 27 de julio de 1665, Diego de Benavides, que años atrás había participado en la construc-

\footnotetext{
${ }^{14}$ Op. Cit. Fol. 252.

${ }^{15}$ Archivo Diocesano de Toledo. Reparación de Templos. Torrejón de Velasco. Legajo: Ma. 9 Exp. 24
} 
ción de la iglesia parroquial de San Salvador de Leganés, inició su visita a la iglesia parroquial de Torrejón de Velasco (lo que quedaba de ella) y elaboró un informe en el que dice:

(...) a ydo y visto la ruyna que hizo la torre de la parroquial de dcha. Villa quando se hundio llevándose tras si la caja de la escalera por donde se subia a la tribuna y una capilla de Nuestra Señora del Rosario y parte del portico del lado del medio dia y otros daños que causso en tejados del cuerpo de la Iglesia y capillas ${ }^{16}$.

A estos destrozos había que añadirle las obras de la sacristía anteriormente mencionadas, que se habían iniciado años atrás y que estaban sin terminar:

(...) asi mismo vio la sacristía començada su fabrica sin haberse acabado habiendo mucho tiempo que se començo, que solo la hallo texada sin estar jarradas las paredes ni hecha la vobeda ni suelo quadrado y muy indecente sin haber donde guardar los bienes y ornamentos ni poderse revestir los sacerdotes (... ${ }^{17}$.

El maestro Diego de Benavides, realizó una traza de la iglesia, con su torre y chapitel, con detalladas instrucciones de cómo debía realizarse la obra. Añadió un pormenorizado presupuesto en el que incluía todos los gastos de reconstrucción de la torre, reparaciones de lo deteriorado por su hundimiento, terminación de las obras de la sacristía, revoco de los cimientos de la iglesia, que estaban descarnados, así como hacer las gradas del Altar Mayor, que eran de yeso y estaban deshechas. Además, había que hacer de nuevo el tejado de la iglesia. El total de esta monumental obra ascendía a la cantidad de 19.333.129 maravedíes. Benavides estuvo comprobando in situ qué materiales habían quedado tras el derrumbe para aprovecharlos, encontrando

la vola de la cruz del chapitel abollada toda y la cruz echa pedazos y las pizarras que segun se informo hasta la madera quedo sin provecho ${ }^{18}$.

Las campanas no sufrieron daños ya que ya habían sido bajadas ante el peligro de derrumbe de la torre, como así ocurrió. En sus instrucciones explica cómo deben ir los cimientos de la iglesia y torre, más anchos que las paredes de la iglesia y de piedra maciza:

\footnotetext{
16 Idem.

17 Idem.

${ }^{18}$ Idem.
} 
Primeramente se an de abrir zanjas asi en la torre como en la pared de escaleras y capilla mayor y entrada de portico, del ancho que muestran las zanjas de piedra que es la suela que han de tener mas anchas que las paredes, que es el grueso de lo que dicen los trazos, y de fondo an de tener hasta diez pies según las catas que ordene se hiciesen hasta para reconocer el fondo hasta lo firme admitiendo que la torre ha de estar maciza hasta la superficie de la iglesia de mampostería y las zanjas con su suela como va todo mostrado. Y la torre desde el superficie referido ha de ir con su cantera como lo muestra el alçado y lo demas todo de albañilería de ladrillo y cal y las paredes de escalera de la capilla y portico tambien haciendo su cimiento de mampostería y en la entrada del portico a cada lado su pedestal de canteria con sus pilastras y frontis tambien de albañilería. Las paredes de la escalera, capilla y portico han de subir hasta veinte y cuatro pies de alto y encima sus colgadijos con la corriente necesaria y tejarlos subiendo la torre todo el alto del alzado y el chapitel empizarrado y emplomadas las molduras con su vola y cruz (... $)^{19}$.

La caída de la torre y los daños que ocasionó supusieron un duro golpe económico para la parroquia. Tras realizarse el presupuesto de Diego de Benavides, se solicitó dinero al Arzobispado pero éste no estaba dispuesto a acceder a sus peticiones. Consideraba al Párroco y al Mayordomo de la iglesia responsables últimos de las obras mientras que el Párroco aseguraba que él no tenía culpa de nada y que la torre se hundió por culpa del maestro de obras. Además, en 1654, como hemos visto, la parroquia había firmado con el Arzobispado de Toledo el acuerdo y concordia para recibir una cantidad de dinero cerrada del Arzobispado a cambio de que la parroquia realizase las obras y las mantuviera en pie por espacio no inferior a 50 años. Como la parroquia había incumplido el acuerdo, el Arzobispado se negó a retener el tercio de los diezmos para la fábrica de la iglesia. Así se inició un pleito que acabó en los tribunales del Arzobispado. El Párroco no pedía dinero extra para reconstruir la torre sino el que pactaron en el acuerdo de concordia de 1654 para las obras de la sacristía, que estaban aún sin terminar. Así estaba el pleito en diciembre 1669:

Joan Aguado, Agente general de la Dignidad Arzobispal de Toledo y sus participes en sus diezmos en el pleito con el Consejo de Justicia y Regimiento

${ }^{19}$ Idem. 
de la Villa de Torrejón de Velasco, respondiendo a su petición de treinta de julio de este año (...) digo que sin embargo de lo que dice y alega que no es cierto y lo niego se ha y debe hacer en todo según y como tengo pedido por lo dicho $y$ alegado en que me afirmo general y favorable y porque los mesmos reparos para que hoy piden la contribución son los que se pactaron en año de 54 y habiendo quedado a quenta de la (...) el ponerlos en execución y conservarlos por cincuenta años buscando maestros por su cuenta y riesgo les basta el pacto y la concordia y estan obligados a cumplir con su obligacion y a ello deben ser compelidos.

Lo otro porque si por mala fabrica se cayo la torre y se llevo parte de la iglesia a y debe resarcir el daño que dio causa a el con acuerdo a la obra falsa y teniendo los contrarios recurso contra los maestros que debieron tomar fianzas a ellos y no a los interesados deven convenir por tanto. Pido se despache provisión con censuras contra el cura de la parroquia de Torrejon mayordomo de su fabrica y la Junta y oficiales del Consejo de dicha Villa para que al termino que seles señalare exiban en este Consejo y pongan en este pleito las sra. Que otorgaron con Mos. Para la fabrica de los reparos a que se contribuyo en el año 54 condiciones de la obra planta y fianzas que recibieron de los maestros con que pactaron y exibidas se me de Srdo. Para pedir de que convenga ${ }^{20}$.

Como las partes no llegaron a un acuerdo, el pleito se prolongó durante años y el apoyo económico del Arzobispado de Toledo quedó suspendido. El Párroco y el Mayordomo de Fábrica de San Esteban Protomártir continuaron las obras sin el apoyo del Arzobispado, contratando maestros por cuenta propia, probablemente con dinero procedente de donaciones y limosnas. Así en 1666 pagaron 4 ducados a Cristóbal de Jarama, maestro de obras de Valdemoro, por hacer una planta para la torre ${ }^{21}$, más 500 reales a Antonio Correa, vecino de Valdemoro, por cuenta de la obra de la sacristía, que estaba concertada en 5.000 reales $^{22}$. A lo único que accedió el Arzobispado fue a enviar en 1667 a Diego de Medina, alarife de Toledo, para que revisase la iglesia con el fin de acondicionarla de tal manera que no fuese peligrosa para los fieles por derrumbes y así se dejó.

\footnotetext{
${ }^{20}$ Idem.

${ }^{21}$ Iglesia Parroquial de Torrejón de Velasco. Libro de Fábrica I. Fol. 298 (Martín, 1942: 4).

${ }^{22}$ Idem.
} 


\section{El proyecto de restauración de Bartolomé Zumbigo y Salcedo (1671).}

Tuvo que pasar algún tiempo y que los ánimos se calmasen entre la parroquia de Torrejón de Velasco y el Arzobispado de Toledo para que se reabriese el tema de la reparación del templo. En esos años el Párroco fue haciendo pequeñas obras y reparaciones a base de limosnas, pero el enorme gasto de levantar de nuevo la torre y otros reparos estaban fuera de su alcance y se quedaron sin hacer. Además estaban en plena construcción del retablo del Altar Mayor, a lo que hay que añadir las obras en la sacristía. En definitiva, estaban comprometidos económicamente y no había dinero para levantar la torre.

\subsection{El proceso constructivo.}

En 1671, 7 años después de haberse hundido la torre, don Fernando García Dávila y Carrillo, Canónigo, Contador Mayor y Juez Ordinario del Arzobispado de Toledo, dio orden para que uno de los técnicos del Arzobispado fuese a Torrejón de Velasco a revisar el estado del templo. El trabajo fue encargado al arquitecto toledano Bartolomé Zumbigo y Salcedo, Maestro Mayor de Obras Reales, muy prestigioso y activo en su época. Zumbigo se trasladó a Torrejón de Velasco y realizó un proyecto de obras con su presupuesto, firmado en Toledo el 23 de mayo de 1671 ante el Mayordomo de Rentas Decimales de Primeros Remates del Arzobispado de Toledo y Notario Público Apostólico, don Blas de Olarte ${ }^{23}$.

Este proyecto resulta especialmente interesante por varias razones: por un lado hace un análisis detallado de las causas técnicas que motivaron el derrumbe de la anterior torre, y por otro, elabora un proyecto en el que evita que se puedan cometer errores técnicos, especificando paso a paso y con lujo de detalles cómo hacer la torre nueva. La torre que definitivamente llegó en pie al siglo XX fue la diseñada por Bartolomé Zumbigo y Salcedo.

En el contrato y condiciones de obra Zumbigo explica la forma de levantar las paredes de la torre, con sus cajones de mampostería y verdugadas de ladrillo tal como se hizo la primera vez. A pesar de esta instrucción el arquitecto recomienda que se haga toda de ladrillo, sin cajones de mampostería, que es como finalmente se hizo. En su informe quedan muy bien explicadas cua-

${ }^{23}$ Archivo Diocesano de Toledo. Reparación de Templos. Torrejón de Velasco. Legajo: Ma. 9. Exp. 23 
les fueron las causas de la caída de la torre: la cal estaba mezclada en proporciones inadecuadas con respecto a la arena, y además estaba mal "cortada".

La torre estaba edificada con cajones de mampostería que se realizaron demasiado altos, con la cal mal mezclada y en malas condiciones y con unos pilares en las esquinas muy delgados. Esto, unido a que las paredes de la torre también eran demasiado delgadas para lo que requería la construcción, y que la torre se hizo un tercio más alta de lo que determinaba la traza original, dio como resultado que el conjunto no aguantase el peso y se desmoronase.

La descripción que hace Bartolomé Zumbigo en el contrato y condiciones de la obra es un manual de las técnicas de construcción del siglo XVII que por su interés histórico detallamos ${ }^{24}$ :

\section{Demolición de los restos de la torre anterior y construcción de sus cimientos:}

En el sitio donde esta plantada la torre se a de demoler la que ya esta en pie haziendo otra conforme a la traza que se para ella enrasando las paredes que hoy tiene hasta la superficie y zepa de ella aprovechando la canteria, dando veinte y quatro pies en quadrado sin la pared de la iglesia que ha de arrimar a ella dcha. torre se a de añadir la zepa que le falta dando a los tres lienzos que no arriman a la dcha. pared dos pies de suela y lanzala que se abriere de seis pies de fondo por estar el firme a quatro pies mazicarla de piedra de la tierra y buena mezcla de cal dejándola para que forje ${ }^{25}$ y se enjugue con la demas zepa que oy tiene que se a de conservar un año y al fin de el se a de levantar el primer cuerpo de canteria y mampostería altizonado como lo muestra la traza en los tres lienzos en cada uno nueve tizones que pasen todo el grueso de las paredes que se eligiran enzima de dcho. zocalo de zinco pies y medio y enrasando dcho. zo-

\footnotetext{
${ }^{24}$ Idem.

25 Según el arquitecto José Luis Alonso García, encargado de los trabajos de restauración de la Iglesia Parroquial de San Esteban Protomártir desde el año 2002, el edificio llevaba como mortero cal hidráulica, la más extendida en las construcciones de la provincia Madrid hasta 1900: La cal tiene la propiedad de endurecer lenta y suavemente únicamente al contacto con el agua y al contacto con el aire aportando este hecho una resistencia final garante de la perennidad de la obra. La cal hidráulica natural pura no necesita ningún añadido químico para funcionar como aglomerante en morteros, superando los resultados que se obtienen con los morteros elaborados como cemento y sus fraguados rápidos. José Luis Alonso García. Plan Director para la Restauración de la Iglesia Parroquial de San Esteban Protomártir en Torrejón de Velasco (Madrid). Pág. 27. Archivo Parroquial de San Esteban Protomártir. Torrejón de Velasco (Madrid).
} 
calo y echadas quatro yladas de ladrillo se dejara en lugar lo que fuere necesario para que forgue la mampostería con la canteria y tendra de salida la planta de dcha. torre a los pies de la iglesia todo el relieve de la cornisa de dcha. iglesia porque no quede cortada como lo muestra la traza. Los sillares tendran en los angulos zinco pies de largo y media bara de alto dos pies de grueso.

Fig. 3. Archivo Diocesano de Toledo. Reparación de Templos. Torrejón de Velasco (Madrid). Legajo

Ma. 29. Expediente 23. Año 1672-1690. Expediente de obras de la iglesia parroquial. Cuaderno sin foliar. Proyecto de reconstrucción de la Iglesia de San Esteban Protomártir por Bartolomé Zumbigo y Salcedo

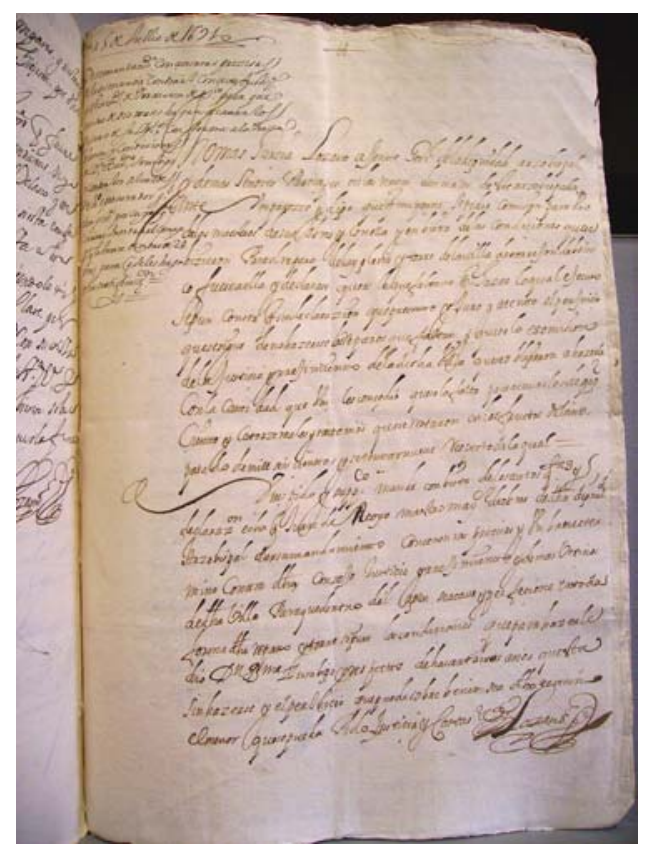

\section{Construcción del primer cuerpo de la torre:}

Es condición que habiendo hecho asiento y en jogadose hasta el fin de dcha. canteria como se ha dicho se a de proseguir dcha. torre el primer cuerpo de sillares de ladrillo en los quatro angulos el mayor de siete pies y el menor de seis y medio y lo demas del medio de caxones de mampostería y verdugos de ladrillo como lo muestra la traza y an de tener cada uno de los caxones con su verdugo media bara de alto labrando dcha. mamposteria de forma que quede mui mazizo a modo de hormigon gastando buena cal la meccla de tres espuertas de arena y dos de cal bien cortada y masada y no se a de gastar hasta que no este aguada y mezclada a lo menos quinze dias a lo mas quarenta y en esta conformidad a de ser toda la cal que se gastare y aunque la dcha. torre pareze que se arruino por ser compuesta de albañilería y mampostería y que oy debiera hazerse de solo albañilería para su duración, dize que esta no fue la causa que uvo otras para que 
dcha. torre pareziese ruina y la mas principal el no estar la mezcla de la cal con las circunstancias dchas. lo otro y que las paredes eran delgadas siendo la torre mas de un terzio mas alta de lo que pudiera cubrir las dchas. paredes lo otro que los cajones de mampostería eran muy altos y los pilares de los angulos muy delgados de la forma que oi se pretende hazer y ejecutar se pueden dar muchos ejemplares en diferentes partes solo le quiere dar en Madrid que es el ladrillo semejante a lo de torrejon en muchas torres que estan ejecutadas en esta mesma forma, vease la torre de la parroquial de San Justo todo lo cual baste para prueba de su seguridad. Asi mismo combendra que la marca del ladrillo sea algo mayor que lo ordinario y que todos los autores combienen en que respecto la grandeza de el edificio se aplique el tamaño de los materiales y si los sillares que muestra la traza no se pudieren sacar del largo y alto que muestra la traza se pondran minorar echando mas yladas hasta cubrir su altura como lo dize la traza.

\section{Construcción del segundo cuerpo de la torre:}

Es condicion que habiendo pasado seis meses que se alla hecho el primer cuerpo de albañilería se podra proseguir el segundo en la mesma conformidad haziendo las dos ventanas que muestra la traza a la parte de poniente que es a donde mira y a la parte de medio dia se aran otras dos, la primera a diez y ocho pies de altura desde la superficie del suelo y la otra otros diez y ocho pies de la primera, para tomar la subida desde la iglesia que si empezase a embarazar las escaleras en otro lado seria preziso tantearlas de otra manera porque los ozinos de la escalera no bengan en las dchas. ventanas y esta misma escalera puede serbir para entrar en la tribuna abriendo la entrada que oy esta condenada.

\section{Construcción del tercer cuerpo de la torre:}

Es condicion que habiendo pasado otros seis meses se ara el terzero cuerpo todo de albañilería como lo muestra la traza dándole de grueso a las paredes tres pies sin la salida de los buelos de la basa relieve de pilastras y la cornisa a de ser de baldosas de a nober, todo lo demas de ladrillo de la tierra guardando la planta y alzado como lo muestra la traza.

\section{Construcción del chapitel:}

Es condicion que se a de hacer el chapitel en conformidad de la traza guardando la forma echando sus telares de viga de terzia y quarta, soleras de vigueta quadrales de terzia y quarta y estribos en los telares de arriba, esquadras de yerro jabarconados camones de vigueta y el nabo o arbol donde se a de fijar la cruz 
baje abajo aziendo otro telar que le abraze y descanse en el y otros dos telares de vigueta en la garganta del chapitel, con sus ocho limas adonde ban a parar los camones y volanderas y otro en la cornisa del pedrestal jabarconados pares y volanderas de madera de a ocho aserradica entablado con tabla de coral que llaman y los camones de la falta tambien de madera de a ocho, todo empizarrado y emplomado donde no se pudiere poner pizarra, con su bola de cobre dorada y los remates de las guardas de plomo doradas y la cruz de yerro dorada, los perfiles y beleta y lo demas de ella dado al olio de negro porque no crie moho y en la bola su platillo arriba y abajo embudo porque no entren las aguas y pudra el nabo, todo muy bien rematado y en conformidad de la traza (...) Es condición que el pedestal o linterna del chapitel no ha de hacerse ochavado sino con chafran o boquillo de media vara en la planta de el viniendo a morir en el angulo u esquina de la cornisa de albañilería conforme lo muestra la traza.

\section{Construcción de la escalera de caracol:}

Es condicion que en el gueco de dcha. torre se a de hazer su escalera caracol quadrado como lo muestra la planta ozinos tabicados doblados y jarrados para arriba y abajo y los antepechos de tres pies y quarto de alto, tabicados doblados y jarrados peldaños de vigueta y forja de yesso de un pie de alto y otro de huella dejando entrada en la tribuna, las mesas soladas de ladrillo tosco de anober. Es condicion que el relox o suela que queda en la planta del terzero cuerpo se ara un suelo quadrado de viguetas con sus bobedillas dejando embroquelado el desembarcadero de la escalera y solarlo de ladrillo tosco de anober y cal rematando los antepechos de los claros de las bentanas con su sardinel como lo muestra la traza.

\subsection{La continuidad del proyecto. Intervenciones a finales del siglo XVIII.}

Este presupuesto dependería también de la mano de obra y de los lugares de donde trajesen los materiales. Tras el proyecto realizado por Zumbigo, el Arzobispado de Toledo accedió a que la parte correspondiente a la parroquia de las rentas decimales fuese retenida para la fábrica y reparación de la igle$\mathrm{sia}^{26}$. En los años siguientes el proyecto de Bartolomé Zumbigo fue realizándose poco a poco siguiendo su traza y sus instrucciones. El 12 de junio de 1691 se hizo una revisión de la evolución de las obras. Algunos de los reparos de Zumbigo estaban aún sin realizar. El 5 de julio don Juan de Reoyo, Maes-

${ }^{26}$ Archivo Diocesano de Toledo. Reparación de Templos. Torrejón de Velasco. Legajo: Ma. 9. Exp. 25

Arte y Ciudad - Revista de Investigación 
tro Mayor de Rentas Decimales del Arzobispado de Toledo, ordena la realización y finalización de las obras según la traza y dictámenes del informe de Bartolomé Zumbigo en vista de que llevaba años sin poder hacerse y del grave perjuicio que significaba para la iglesia, para los fieles y para todos los vecinos del pueblo.
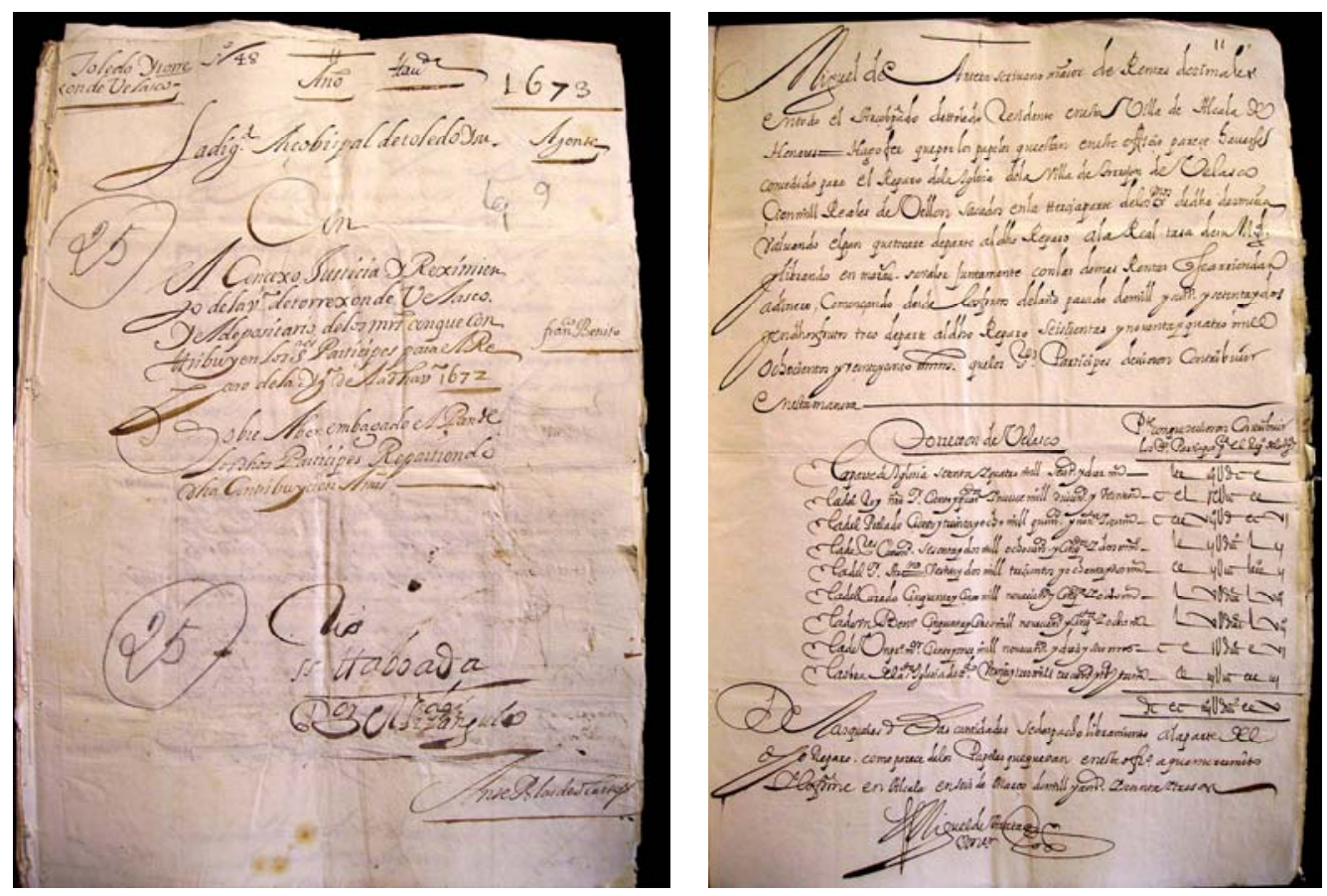

Figs. 4 y 5. Archivo Diocesano de Toledo. Reparación de Templos. Torrejón de Velasco. Legajo. Ma. 9 Expediente 25. Documento firmado por don Miguel de Arteta, Secretario Mayor de Rentas Decimales del Arzobispado de Toledo, dando licencia para que la tercera parte del diezmo fuese destinado a las reparaciones del templo, concediendo la cantidad de cien mil reales de vellón. Firmado el 6 de marzo de 1673. La Dignidad Arzobispal de Toledo y su Agente en el Consejo de Justicia y Reximiento de la Villa de Torrejón de Velasco y el depositario de los maravedíes con que contribuyen los Señores partícipes para el reparo de la Iglesia de la dicha Villa 1672. Sobre Aber embargado el pan de los dichos partícipes repartiendo dicha contribución.

A través de este informe sabemos que en 1691 la torre tenía ya construido sus nuevos cimientos, más profundos, su basamento de sillares de piedra y sus tres cuerpos. Aún faltaba por hacer el chapitel. Mientras terminaban de construir la escalera de caracol de la torre, que se encontraba en sus últimos tramos, habían cubierto el tercer cuerpo correspondiente al campanario con un tejadillo 
a dos aguas de forma provisional. La suma total de los tres cuerpos daban una altitud superior a lo planificado por Bartolomé Zumbigo, pero el grosor de los muros que él dispuso hacía que la construcción fuese suficientemente fuerte para soportar este exceso de altura sin peligro. El informe de 1691 dice de ella que está bien obrada y executada conforme a Arte y con buenos materiales y muy fuerte toda la albañilería ${ }^{27}$. A pesar de que se dio la orden de acabar las obras, esto no significó que se realizasen más deprisa. Todo siguió su curso, atendiendo a aquel famoso dicho de que "las cosas de palacio van despacio".

\section{Nuevas obras y reformas en los siglos XIX y XX.}

Algunas fechas importantes sobre la fábrica de la iglesia son difíciles de contrastar pero las agregamos en este trabajo porque fueron aportadas por párrocos de la iglesia y por ajustarse a las fechas del resto de los documentos encontrados en el Archivo Diocesano de Toledo. Según las anotaciones del párroco don Daniel Ortiz realizadas en 1937 a partir de datos copiados de los Libros de Bautismos por el párroco don Narciso Martín en 1893, el 1 de agosto de 1698 cayó una centella en la torre, rompió una pared y destrozó el órgano y el chapitel de la torre ${ }^{28}$. De 1691 a 1698 van 7 años, tiempo más que suficiente para reconstruir el chapitel. Sin embargo no hay constancia documental en los libros de fábrica consultados en el Archivo Diocesano de Toledo sobre ésta circunstancia. En cuanto al órgano que se menciona en la cita de don Daniel Ortiz y que quedó destruido por la centella, la caída de la torre en 1665 se llevó tras de sí la caja de la escalera por donde se subía a la tribuna (el coro) y parte del pórtico del lado de Mediodía. La descripción de los daños según Diego de Benavides, Maestro de Albañilería ${ }^{29}$, no especifica si la propia tribuna recibió daños ni si la caída de la torre pudo afectar al órgano de Nicolás de Mayo. En cualquier caso, lo que sí puede documentarse es que en 1779 se compró otro órgano, de José Loytegui, del que hablaremos más adelante, lo que indica que el de Nicolás de Mayo en algún momento anterior se perdió.

Según las anotaciones del párroco don Daniel Ortiz el 20 de agosto de 1693 se estrenó la Pila Bautismal ${ }^{30}$, lo que indicaría que para esta fecha ya estaba cons-

\footnotetext{
27 Idem.

${ }^{28}$ Archivo Parroquial de San Esteban Protomártir. HR (1) CUA.1937. 23 ago. P. 8.

${ }^{29}$ Archivo Diocesano de Toledo. Reparación de Templos. Torrejón de Velasco. Legajo: Ma. 9. Exp. 24

${ }^{30}$ Archivo Parroquial de San Esteban Protomártir. HR (1) CUA.1937. 23ago. P. 8.
} 
truido el baptisterio. También se menciona el 14 de agosto de 1705 como fecha de terminación del chapitel ${ }^{31}$, totalmente factible si tenemos en cuenta que en 1691 ya estaban construidos los tres cuerpos y que de ser cierta la noticia sobre la destrucción del chapitel por la caída de una centella en 1698, daría tiempo a reconstruirlo y tenerlo terminado para 1705. Don Narciso Martín aporta un coste del chapitel de 22.915 reales, precio bastante inferior a lo presupuestado por Bartolomé Zumbigo en 1671. La diferencia de precio podría deberse a que se pudieron reutilizar algunos materiales o a que no se trató de una reconstrucción total sino de reparos.

En 1784 se pusieron nuevas las gradas del Altar Mayor y los púlpitos del Evangelio y la Epístola, todo en piedra blanca de Colmenar, costeado a expensas de la obra pía del doctor Juan Dionisio Navarro ${ }^{32}$. También en piedra de Colmenar se colocaron las tarimas de los cuatro altares de la Capilla Mayor (altares de San José, Cristo de la Ascensión, Virgen del Rosario y Virgen del Amor Hermoso).

A partir de aquí, se podía dar por concluida la fábrica de la iglesia, lenta, cuajada de impedimentos, desastres, pleitos, y también muchos aciertos y sobre todo, mucho esfuerzo y voluntad por parte de sus párrocos, mayordomos y de los fieles de Torrejón de Velasco para tener en el pueblo una iglesia hermosa y digna. Desde entonces hasta nuestros días prácticamente todos los años se han producido trabajos de reparación y mantenimiento. Sirva como ejemplo que la cubierta de la iglesia ha requerido una renovación profunda cada 40 o 50 años, además de constantes reparaciones y labores de mantenimiento de los maderajes de la cubierta, bóvedas, tejas, reposición de las piedras de los aleros, solado, carpintería de las puertas, etc.

A finales del siglo XIX la parroquia estaba situada casi en un extremo del pueblo, aunque es de suponer que en algún tiempo debió estar mas céntrica, limitando al Norte con las Tierras de Tiburcio Rodríguez, al Mediodía con la Carretera Provincial y Plaza de la Iglesia, al Oriente con la Casa de doña Luisa Martín y la

\footnotetext{
${ }^{31}$ Archivo Diocesano de Toledo. Reparación de Templos. Torrejón de Velasco. Legajo: Ma. 9. Exp. 23 32 El doctor Juan Dionisio Navarro había creado una Memoria en el año 1684, administrada por los Párrocos de San Esteban Protomártir, en cuyas cláusulas se estipulaba que una parte de las rentas se destinasen al ornato del Altar Mayor de la iglesia. Archivo Diocesano de Getafe. Torrejón de Velasco. Caja 1 de Fábrica: 19 de abril de 1907. Carta del Párroco don Narciso Martín al Obispado de Madrid-Alcalá.
} 
Calle del Santísimo y en el lado de Poniente con dicha carretera Provincial (...) . $^{33}$ Según los datos de la Topografía Catastral de España fechados el 19 de julio de 1864, siendo cura párroco don Sebastián Vargas, y alcalde de la Villa de Torrejón de Velasco don Francisco Pedrero, la parcela perteneciente a la iglesia tenía 9 áreas de 35,48 metros edificados, 5 áreas de 64,51 metros de cementerio y 10 áreas de $16^{\prime} 12$ metros de patios ${ }^{34}$.

El edificio estaba ubicado en una plazoleta, rodeada por un muro de piedra y cal de un metro de altura por unas partes y medio metro por otras. Esta plazoleta, propiedad de la iglesia, era antiguamente el cementerio, pero después dejó de utilizarse como tal y se plantaron algunos árboles como adorno y sombra. Este jardín tenía cinco accesos, dos de ellos con escalones en mal estado y el resto sin escalones. La iglesia tenía antiguamente tres entradas al templo, con puertas de hierro. A finales del siglo XIX, sólo dos entradas a la iglesia permanecían activas, la del lado de Levante y la del lado de Mediodía, y tenían sendas pilas de agua bendita, de un metro de altura y en cabida de dos cántaros $^{35}$. La puerta ubicada en la parte Norte, entre los altares de San José y Cristo de la Ascensión, fue condenada y en ese espacio se construyó una capilla que fue consagrada a la Virgen del Carmen.

En cuanto al interior del templo, el suelo de la Iglesia estaba conformado de distintos materiales: mientras se estuvieron haciendo enterramientos dentro de la iglesia, el suelo, como hemos visto, era de losetas. A finales del siglo XIX el primer tramo de la nave era de ladrillo y el resto hasta el Altar Mayor era de tablas de madera machihembradas, menos los pórticos que eran de piedra de Esquivias. El piso de la sacristía era de tablas de madera y el de la Capilla de los Hierros de baldosín de Ariza. En el siglo XX se acomodó el templo a las nuevas necesidades como la instalación de luz eléctrica en $1911^{36}$, agua corriente, sanitario o sistema de canalización al exterior de las aguas del sanitario.

\footnotetext{
${ }^{33}$ Archivo Diocesano de Getafe. Torrejón de Velasco. Caja 1 de Fábrica: Inventario de la Parroquia de Torrejón de Velasco para entregarlo a la Santa Visita. (Sin foliar) por el párroco Lic. Narciso Martín.

34 Topografía Catastral de España. Ref. 1984098. Instituto Geográfico. Madrid. Copia en Archivo Parroquial de San Esteban Protomártir. RH (1) 19 jul. 1864.

35 Archivo Diocesano de Getafe. Torrejón de Velasco. Caja 1 de Fábrica: Inventario del Párroco Lic. Narciso Martín.

${ }^{36}$ Idem. Solicitud del Alcalde para colocar en la fachada de la iglesia unas palomillas para la instalación de electricidad en el pueblo.
} 


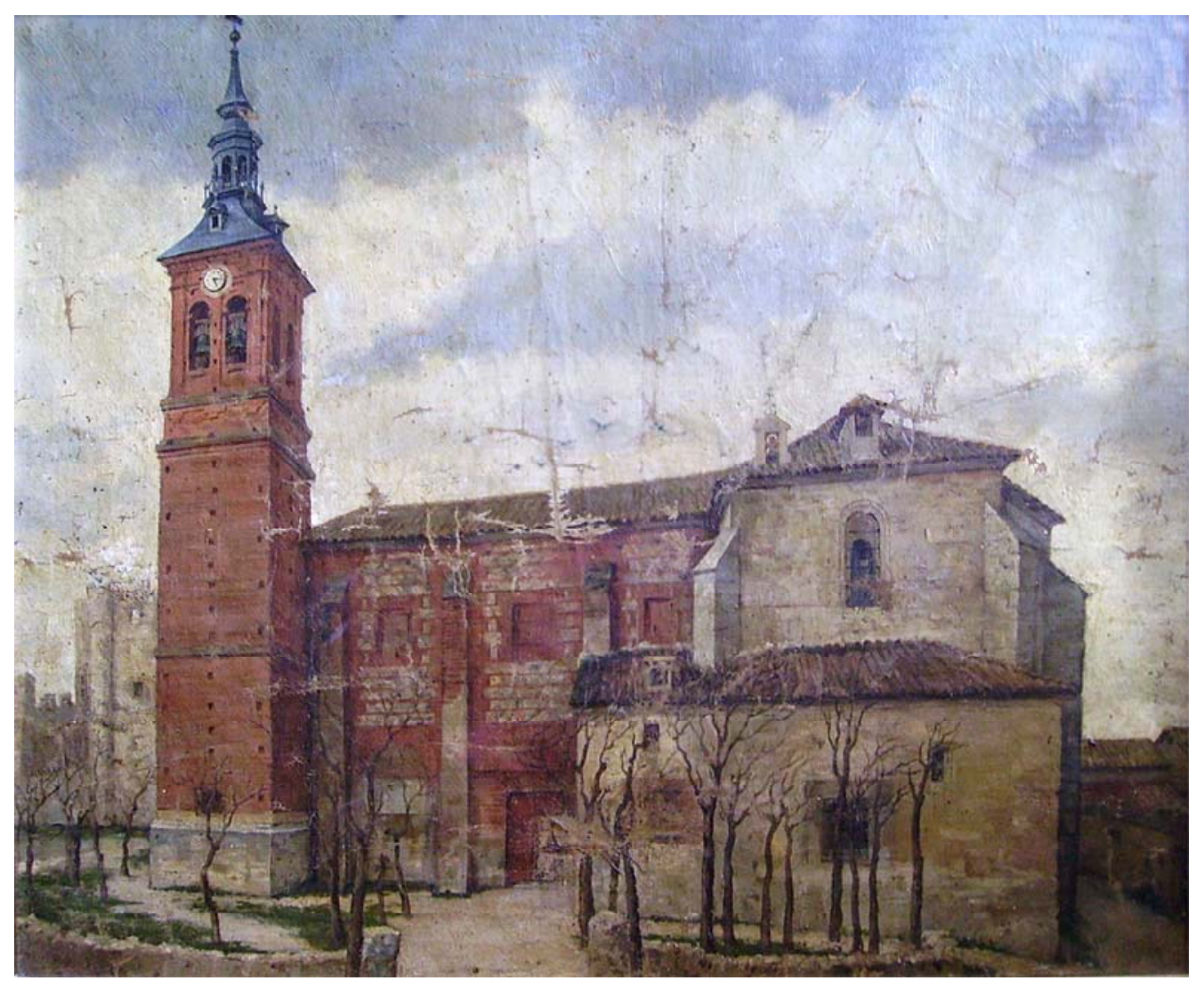

Fig. 6 (sup). Iglesia de San Esteban Protomártir. Torrejón de Velasco. Óleo sobre lienzo. Autor desconocido. Según la propietaria, vecina de Torrejón de Velasco, data de antes de la Guerra Civil española.

Fig. 7 (drch). Iglesia parroquial San Esteban Protomártir de Torrejón de Velasco. Archivo parroquial. Es una de las poquísimas fotografías que se conservan anteriores a la Guerra Civil española, donde se puede apreciar las capillas laterales que tenía y su chapitel. 
Iglesia de San Esteban Protomártir de Torrejón de Velasco (Madrid). Orígenes...

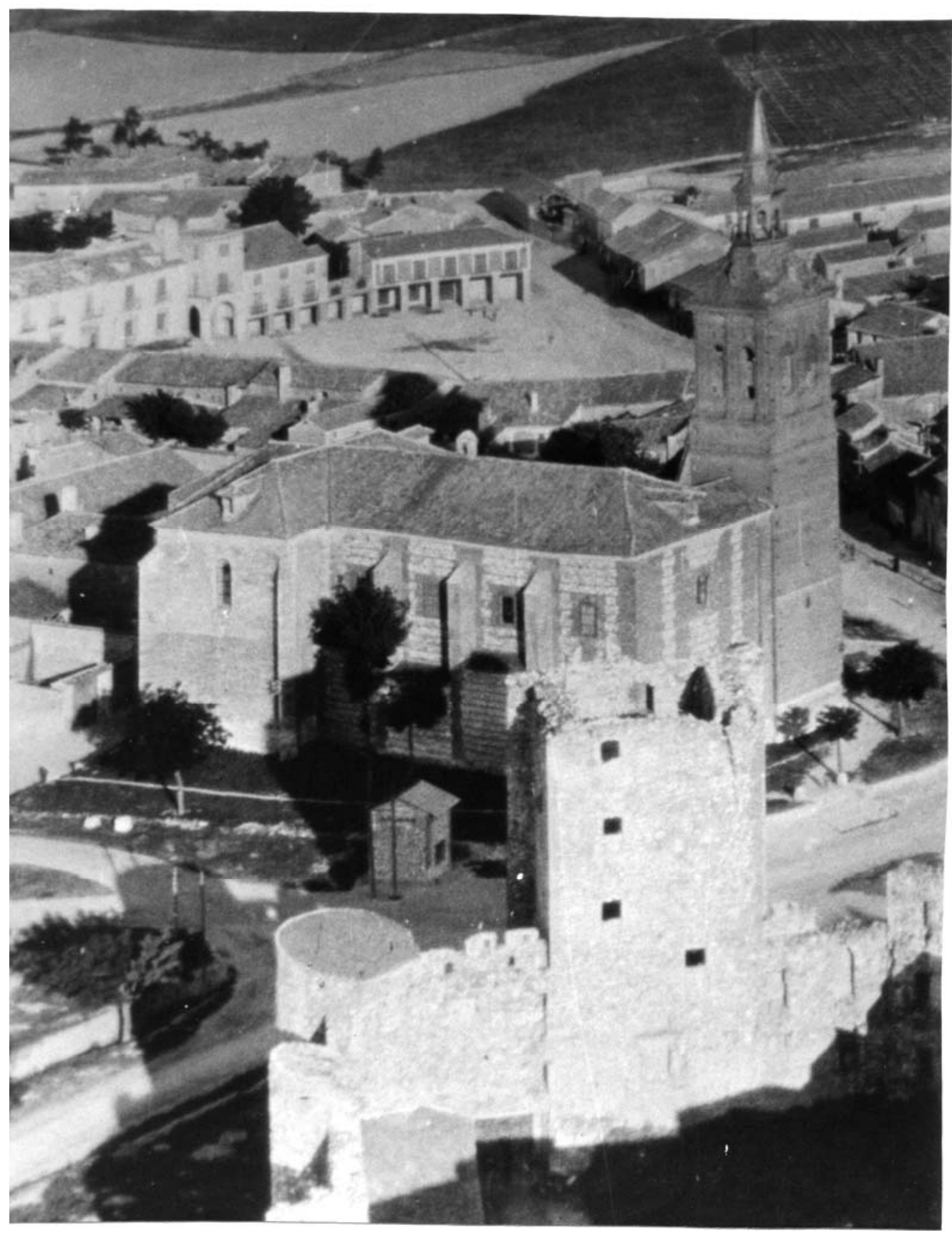

Arte y Ciudad - Revista de Investigación 


\section{Fuentes Documentales.}

BIBLIOTECA NACIONAL: Aljamas, padrones, arrendamientos y otros papeles pertenecientes a los moros y judíos de Castilla. Carta de Alfonso XI, sobre la moratoria dada a los cristianos por las deudas de los judíos, 1341 (h. 56$57 \mathrm{v}$ ). Idem, para que los judíos paguen tributos por las heredades que tuviesen en Toledo, Gálvez, Torre Esteban Ambran, Parla, Torrejón de San Sebastián y Polvoranca, 1343. h. 58-59r

ARCHIVO HistóRICO NACIONAL. Sección Clero Caja. 3.072

ARChivo Histórico Del Monasterio De SANTO DOMingo El ReAl (TOLEDO): № 1018

ARChivo Diocesano De Toledo. Reparación de Templos. Torrejón de Velasco. Legajo: Ma. 9 Expedientes 21, 22, 23, 24, 25

Archivo Parroquial De SAN EstÉbAn PROTOMÁRTIR: AlOnSO García, José Luis. Plan Director para la Restauración de la Iglesia Parroquial de San Esteban Protomártir en Torrejón de Velasco (Madrid). Pág. 27.

__ C(1) EST.San José.1621

__ HR(1)CUA.1937.23ago. Pág. 8

__ HR(1)CUA.1937.23ago. Pág. 8

__ $\mathrm{RH}(1) 19 \mathrm{jul} .1864$

Archivo Histórico De Protocolos Notariales De Madrid: P.3597, Fol. 1957v-1959v. Petición de Francisco Martín Tamborino, de profesión entallador, para ser enterrado dentro de la iglesia de Torrejón de Velasco. 26 de noviembre de 1623.

Archivo Diocesano De Getafe: Torrejón de Velasco. Caja 1 de Fábrica: 19 de abril de 1907. Carta del Párroco don Narciso Martín al Obispado de Madrid-Alcalá.

— Torrejón de Velasco. Caja 1 de Fábrica: Inventario del Párroco Lic. Narciso Martín. Inventario de la Parroquia de Torrejón de Velasco para entregarlo a la Santa Visita.(Sin foliar)

_ Torrejón de Velasco. Caja 1 de Fábrica: Inventario del Párroco Lic. Narciso Martín. Loc. Cit; 
_ Torrejón de Velasco. Caja 1 de Fábrica: solicitud del Alcalde para colocar en la fachada de la iglesia unas palomillas para la instalación de electricidad en el pueblo.

InSTITUTO GEOGRÁfiCO. Madrid. Topografía Catastral de España. Ref.1984098.

\section{Bibliografía}

BORDEJÉ GARCÉS, Federico (1956). Itinerarios de Castillos. Castillos del Oeste de la Provincia de Madrid. II. Villaviciosa de Odón y Torrejón de Velasco. Boletín de la Asociación de Amigos de los Castillos. IV.

DE ANDRES, Gregorio (1986). Una Visita al Arcedianato de Madrid en 1427. Cuadernos de Historia y Arte. Centenario de la Diócesis de Madrid-Alcalá. Vol. III. Ed. Arzobispado de Madrid-Alcalá. Madrid.

DiAZ Prieto, Tomás (2005). “El Castillo de Torrejón de Velasco". Castillos de España. Publicación de la Asociación Española de Amigos de los Castillos. № 137, 138, 139. Madrid, págs. 32-38.

FITA, Fidel (1886): La Judería de Madrid en 1391. Boletín de la Real Academia de la Historia. Tomo 8, Año 1886.

GEANINI TORRES, Antonio (1991): Hallazgos Visigodos en la Construcción del Gasoducto de Madrid. Arqueología, Paleontología y Etnografía. Vol. 4. Ed. Consejería de Cultura. Madrid.

Martín GaláN, Manuel M., Juan A. Sánchez Belén (1992): Ejecución de las Transcripciones Literales de los Manuscritos de las Respuestas al Cuestionario Enviado por el Cardenal Lorenzana, de los Resúmenes Coetáneos y de los Resúmenes de Tomás López, Acerca de los Términos de la Actual Provincia de Madrid. Torrejón de Velasco. Vol. 4. Fotocopia del original mecanografiado y fechado en 1984. Madrid.

MARTín MARTín, José L (2003): El clero rural en la Corona de Castilla. La Iglesia en el mundo Medieval y Moderno. Instituto de Estudios Almerienses. Almería.

MARTíN, Ricardo (1942): “Un retablo destruido”. Arte Español. Madrid. (Ref. Libro de Fábrica de la Iglesia Parroquial de Torrejón de Velasco. Libro I).

MARTín PÉREZ, Andrés (1888): Guía de Madrid y su Provincia. Madrid. 
MARTín-SerRano García, Pilar (1991): Torrejón de Velasco. Arquitectura y Desarrollo Urbano. Comunidad de Madrid. Vol. XIII. Dirección General de Arquitectura. Colegio Oficial de Arquitectos. Madrid.

Montero Vallejo, Manuel (1987). El Madrid Medieval. Ed. El Avapies. Madrid.

SEGURA GRAINO, Cristina (2002). El origen islámico de Madrid y las relaciones con los reinos cristianos. Ciclo de conferencias "Testimonios del Madrid Medieval. El Madrid Musulmán”. Ed. Museo de San Isidro. Madrid.

VIGIL-ESCALERA GUIRADO, Alfonso (1997): Informe preliminar: Excavación de sondeos arqueológicos en el castillo de Torrejón de Velasco (Madrid) Campaña 1997. Ed. Sociedad Cooperativa Arqueológica. Madrid. 